\title{
Disentangling effects of climate and land use on biodiversity and ecosystem services-A multi-scale experimental design
}

\author{
Sarah Redlich $^{1}$ (D) | Jie Zhang ${ }^{1}$ | Caryl Benjamin ${ }^{2}$ (D) | Maninder Singh Dhillon ${ }^{3}$ (D) | \\ Jana Englmeier ${ }^{4}$ (D) | Jörg Ewald ${ }^{5}$ (D) | Ute Fricke ${ }^{1}$ (D) | Cristina Ganuza ${ }^{1}$ (D) | \\ Maria Haensel $^{6}$ | Thomas Hovestadt ${ }^{7}$ (D) | Johannes Kollmann ${ }^{8}$ (D) | Thomas Koellner \\ Carina Kübert-Flock $^{3}$ (D) | Harald Kunstmann ${ }^{9,10}$ (D) | Annette Menzel ${ }^{2}$ \\ Christoph Moning $^{5}$ | Wibke Peters ${ }^{11}$ (i) | Rebekka Riebl ${ }^{6}$ (i) | Thomas Rummler ${ }^{9}$ \\ Sandra Rojas-Botero ${ }^{8}$ (D) | Cynthia Tobisch ${ }^{5}$ (D) | Johannes Uhler ${ }^{4}$ (D) | Lars Uphus ${ }^{2}$ | \\ Jörg Müller ${ }^{4,12}$ (i) | Ingolf Steffan-Dewenter ${ }^{1}$ (D) \\ ${ }^{1}$ Department of Animal Ecology and Tropical Biology, Julius-Maximilians-University, Würzburg, Germany; ${ }^{2}$ Ecoclimatology, TUM School of Life Sciences, \\ Technical University of Munich, Freising, Germany; ${ }^{3}$ Institute of Geography and Geology, Department of Remote Sensing, Julius-Maximilians-University, \\ Würzburg, Germany; ${ }^{4}$ Field Station Fabrikschleichach, Department of Animal Ecology and Tropical Biology, Julius-Maximilians-University, Würzburg, Germany; \\ ${ }^{5}$ Institute of Ecology and Landscape, Weihenstephan-Triesdorf University of Applied Sciences, Freising, Germany; ${ }^{6}$ Professorship of Ecological Services, \\ Bayreuth Center of Ecology and Environmental Research (BayCEER), University of Bayreuth, Bayreuth, Germany; ${ }^{7}$ Theoretical Evolutionary Ecology Group, \\ Department of Animal Ecology and Tropical Biology, Julius-Maximilians-University, Würzburg, Germany; ${ }^{8}$ Chair of Restoration Ecology, TUM School of Life \\ Sciences, Technical University of Munich, Freising, Germany; ${ }^{9}$ Chair for Regional Climate and Hydrology, Institute of Geography, University of Augsburg, \\ Augsburg, Germany; ${ }^{10}$ Institute of Meteorology and Climate Research (IMK-IFU), Karlsruhe Institute of Technology-Campus Alpin, Garmisch-Partenkirchen, \\ Germany; ${ }^{11}$ Department of Biodiversity, Conservation and Wildlife Management, Bavarian State Institute of Forestry, Freising, Germany and ${ }^{12}$ Bavarian Forest \\ National Park, Grafenau, Germany
}

Correspondence

Sarah Redlich

Email: sarah.redlich@uni-wuerzburg.de

Ingolf Steffan-Dewenter

Email: ingolf.steffan@uni-wuerzburg.de

Funding information

Bavarian Ministry of Science and the Arts WOA Institution: JULIUS-MAXIMILIANSUNIVERSITAET WURZBURG

Handling Editor: Kate Quigley

\section{Abstract}

1. Climate and land-use change are key drivers of environmental degradation in the Anthropocene, but too little is known about their interactive effects on biodiversity and ecosystem services. Long-term data on biodiversity trends are currently lacking. Furthermore, previous ecological studies have rarely considered climate and land use in a joint design, did not achieve variable independence or lost statistical power by not covering the full range of environmental gradients.

2. Here, we introduce a multi-scale space-for-time study design to disentangle effects of climate and land use on biodiversity and ecosystem services. The site selection approach coupled extensive GIS-based exploration (i.e. using a Geographic information system) and correlation heatmaps with a crossed and nested design covering regional, landscape and local scales. Its implementation in Bavaria (Germany) resulted in a set of study plots that maximise the potential range and independence of environmental variables at different spatial scales.

3. Stratifying the state of Bavaria into five climate zones (reference period 19812010) and three prevailing land-use types, that is, near-natural, agriculture and

This is an open access article under the terms of the Creative Commons Attribution License, which permits use, distribution and reproduction in any medium, provided the original work is properly cited.

(c) 2021 The Authors. Methods in Ecology and Evolution published by John Wiley \& Sons Ltd on behalf of British Ecological Society 
urban, resulted in 60 study regions $(5.8 \times 5.8 \mathrm{~km}$ quadrants) covering a mean annual temperature gradient of $5.6-9.8^{\circ} \mathrm{C}$ and a spatial extent of $\sim 310 \times 310 \mathrm{~km}$. Within these regions, we nested 180 study plots located in contrasting local landuse types, that is, forests, grasslands, arable land or settlement (local climate gradient $4.5-10^{\circ} \mathrm{C}$ ). This approach achieved low correlations between climate and land use (proportional cover) at the regional and landscape scale with $|r \leq 0.33|$ and $|r \leq 0.29|$ respectively. Furthermore, using correlation heatmaps for local plot selection reduced potentially confounding relationships between landscape composition and configuration for plots located in forests, arable land and settlements.

4. The suggested design expands upon previous research in covering a significant range of environmental gradients and including a diversity of dominant land-use types at different scales within different climatic contexts. It allows independent assessment of the relative contribution of multi-scale climate and land use on biodiversity and ecosystem services. Understanding potential interdependencies among global change drivers is essential to develop effective restoration and mitigation strategies against biodiversity decline, especially in expectation of future climatic changes. Importantly, this study also provides a baseline for long-term ecological monitoring programs.

\section{KEYWORDS}

biodiversity, climate change, ecosystem functioning, insect monitoring, land use, space-fortime approach, spatial scales, study design

\section{1 | INTRODUCTION}

Human actions are threatening the interdependent yet fragile balance of the biosphere, with far-reaching consequences for the diversity of plants (Brummitt et al., 2015) and animals (Dirzo et al., 2014). As biodiversity contributes a wealth of ecological services, cascading effects and reassembly of communities jeopardise human well-being and biosphere's resilience against current and future disturbance (Chaplin-Kramer et al., 2019; Mori et al., 2018). Many of the services, such as food provisioning, decomposition or maintenance of soil fertility, rely on biotic interactions potentially sensitive to global change. This is especially true for regulating services provided by the highly diverse class of insects: pollination and pest regulation, both shown to strongly affect food production (Dainese et al., 2019; Duffy et al., 2017). Reported losses of insect biomass and abundances across Europe and the globe are therefore particularly worrisome (Hallmann et al., 2017; Seibold et al., 2019; Wagner, 2020). Yet the full cross-taxon magnitude of declines and the relative contributions of man-made drivers remain poorly understood.

One of the greatest threats to biodiversity is land-use change, the transformation of terrestrial ecosystems for infrastructure, human settlements and the production of crops, animals and timber (Newbold et al., 2015). Landscape simplification, urbanisation, deforestation and agricultural intensification alter environmental conditions and the availability of habitats and resources, but also the structure of entire landscapes, that is, their composition (amount of different habitat types) and configuration (spatial arrangement and patch size of habitats, commonly assessed as 'edge density'). Both variables are often highly correlated (Fahrig et al., 2011) and might interact in nonlinear ways (Martin et al., 2019; Redlich et al., 2018), while attempts to disentangle them by reducing the parameter space may lower the statistical power of study designs (Figure 1). Concurrently, land-use effects on biodiversity and ecosystem services depend on spatial scaling, the degree of specialisation and movement capability of taxa and ecological processes considered (Piano et al., 2020; Wiens, 1989), with important implications for population dynamics, the diversity of fungi, plants and animals, and in consequence for ecosystem functions and services (Díaz et al., 2019; Foley et al., 2005; Newbold et al., 2015). While macroecological processes such as environmental filtering determine regional species pools, species diversity and population abundances at smaller spatial scales relate to multi-habitat use, dispersal ability, resource availability and trophic interactions. For instance, large-scale urbanisation reassembles terrestrial and aquatic invertebrate communities (Piano et al., 2020), but local conversion from natural habitat to cropland reduces species abundances and the multitrophic functional biodiversity in agroecosystems (Provost et al., 2020) with flow-on effects for pollination, pest regulation and crop productivity (Dainese et al., 2019). 
(a)

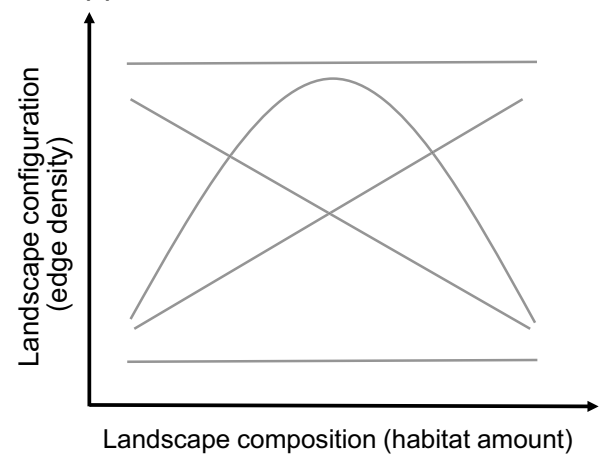

- Random site selection

- Reduced parameter space

(b) Heatmap based preselection

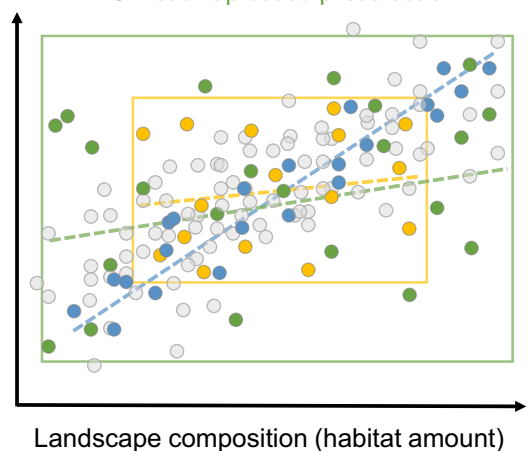

FIGURE 1 Disentangling effects of landscape composition and configuration in large-scale ecological studies. Relationship between variables can be positive, negative, nonlinear or independent, depending on habitat amount, habitat type and region (a). Random selection of study plots regularly results in significant correlations between variables (blue points, b), while posterior exclusion of plots reduces correlations but also the covered parameter space (yellow rectangle and points, b). A priori knowledge of potential correlations and targeted selection of study plots using heatmaps reduces correlations and increases the parameter space (green rectangle and points). Dashed trend lines in blue, yellow and green in (b) indicate the expected change of landscape variable correlations depending on the site selection approach

Climate is another major driver of biodiversity. Long-term data on species distributions along latitudinal and elevational climatic gradients demonstrate significant poleward and upward shifts of species' ranges driven by global warming (Parmesan, 2006). In the future, extinction risks across all animal taxa-but particularly ectothermic organisms such as insects-may further increase with accelerating climate change (Urban, 2015; Warren et al., 2018). Similarly, plant community richness is likely to decrease in temperate climates, where the range of thermal tolerances in regional species pools is narrow (Harrison, 2020). Both for animals and plants, the risk of extinction and the potential to expand their geographic range in response to climate change largely depend on species-specific traits such as the climatic tolerance and the capacity to disperse and colonise new habitats (Estrada et al., 2016). As a consequence, individual species' traits and the resulting ratio between climate change winners and losers drive the overall impact of climate change on biodiversity and the restructuring of communities.

Specific land-use types may prevent climate-induced range shifts and accelerate extinctions (Fox et al., 2014; Peters et al., 2019), especially in case of less mobile specialists (Fourcade et al., 2021; Warren et al., 2001). Alternatively, (in)vertebrate communities in anthropogenic land-use types may shift towards drought- and warmingtolerant species (Williams \& Newbold, 2020). Understanding the independent and combined impact of land-use and climate change on biodiversity, community composition and ecosystem services is needed to predict future changes and allow for management strategies that mitigate further losses. However, $<10 \%$ of available studies analyse combinations of both drivers (Rillig et al., 2019), and commonly observed correlations make it difficult to disentangle individual effects (Peters et al., 2019). First, land use is driven by current and historic demographic and political settings, environmental conditions (e.g. soil characteristics) and climatic parameters, often causing geographic clustering of land-use types (Dale, 1997).
Second, land-use change may feed back to the atmosphere and alter regional climate including water availability by precipitation (Laux et al., 2017; Williams \& Newbold, 2020). Furthermore, as long-term data on climate, land use and biodiversity are currently lacking, recently established monitoring schemes will not deliver sufficient data in the near future and time-series analysis may be prone to biases (Didham et al., 2020).

Here, we report on a step-by-step protocol (Figure 2) for a comprehensive study design that systematically combines full gradients of climate and land use at various spatial scales to investigate interacting effects on biodiversity of a wide range of primarily terrestrial taxa. This method was developed within the framework of a large-scale interdisciplinary climate research project (LandKlif, www.landklif.biozentrum. uni-wuerzburg.de). The stratified, nested design used intensive GISbased exploration of potential study regions and a new site-selection approach based on heatmaps to reduce potential pitfalls of ecological studies on effects of land-use and climate: (a) non-independence of climate and land-use variables, and correlations among land-use related composition and configuration variables; (b) restrictions in gradient range or the number of spatial scales considered (i.e. reduction of parameter space); and (c) lacking monitoring data for biodiversity and ecosystem services. The described method can be useful for similar multi-scale research programs and long-term ecosystem monitoring, but will also allow for predictions of potential interactive impacts of climate and land use in a space-for-time approach.

\section{MATERIALS AND METHODS}

\section{1 | Study area}

The three-step study design (Figure 2) was implemented in 2019 in Bavaria, Southern Germany. With an area of around $70,000 \mathrm{~km}^{2}$ and 


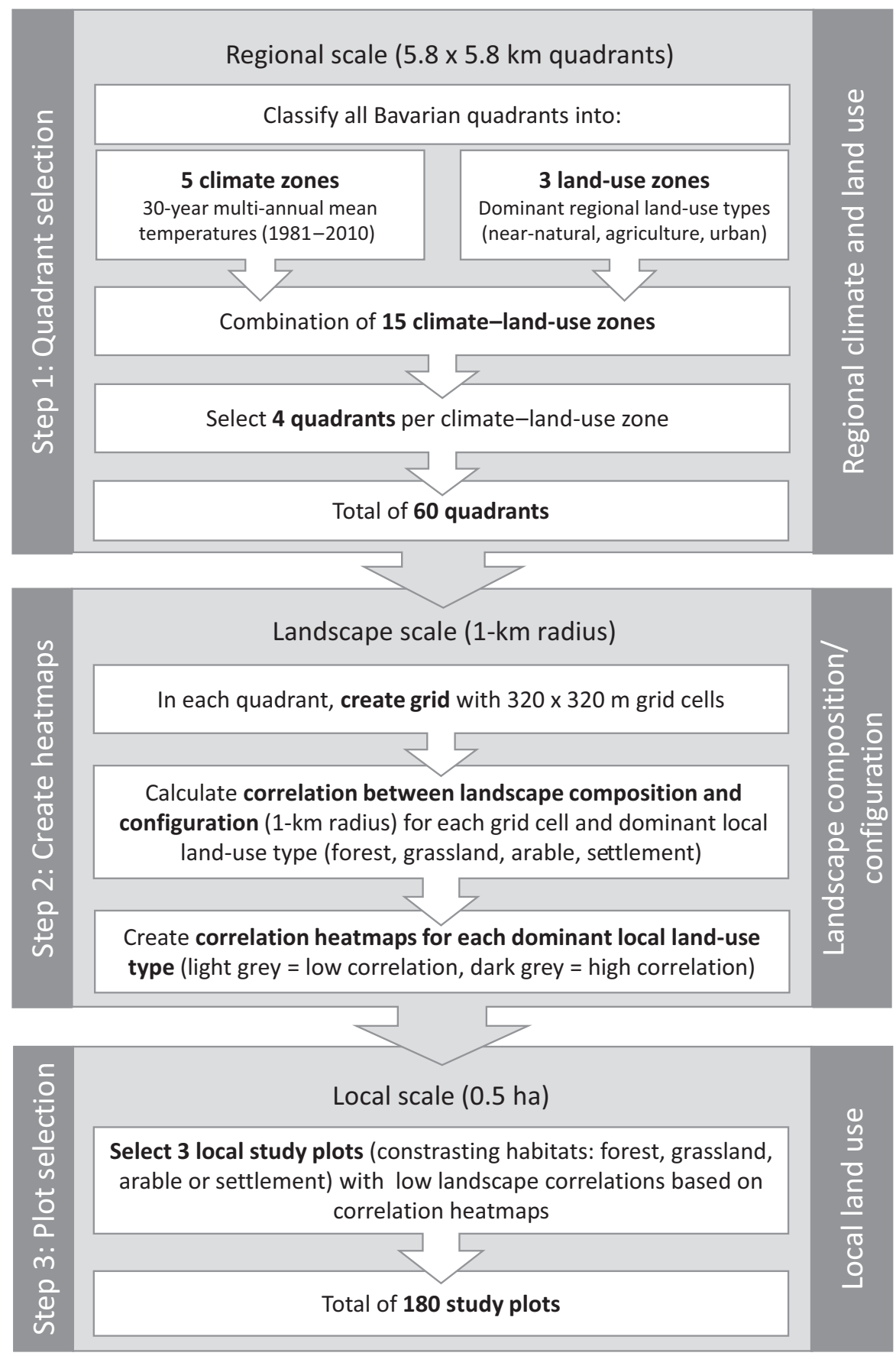

FIGURE 2 General overview of threestep plot selection process, exemplified by a large-scale interdisciplinary climate research project in Bavaria, Germany. Step 1: Selection of 60 study quadrants (i.e. study regions) based on 15 climateland-use combinations. Step 2: Creation of heatmaps to disentangle landscape composition and configuration variables in 1-km radius. Step 3: Based on heatmaps, selection of final 180 study plots in contrasting local land-use types
13 mil. inhabitants, it is the largest and second most populous state of Germany (Bayerisches Landesamt für Statistik, 2020). The land use of Bavaria is dominated by human influences, but also comprises less intensively used near- or semi-natural areas. While 7\% constitute urban areas and 53\% agricultural land or managed grassland, the remaining $40 \%$ are covered by (mostly managed) forests, nature protection areas and other near-natural habitats (CORINE, 2012). Bavaria's size and heterogeneity of climate and anthropogenic influences makes it a suitable pilot region for studying and disentangling effects of climate and land use in temperate regions and at the regional, landscape and local scale.

\subsection{1 | Step 1-Selection of study regions} ('quadrants') based on climate and land-use zones

At the regional scale, a stratified sampling approach ensured complete coverage of climate and land-use gradients and largely uncorrelated, orthogonal parameter combinations of both (Figure 2). Regions were hereby defined as existing $5.8 \times 5.8 \mathrm{~km}$ quadrants, which build the cells of a spatial grid covering the whole of Bavaria ('TK25' topographical map established in 1868, scale 1:25,000). The scale of the TK25 mapping system is large enough to assess effects of climate and accommodate three spatially independent study plots 
(see below), while maximising regional climate and land-use contrasts. Additionally, historic land use maps and floristic and faunistic inventories allow to evaluate changes over time.

To select potential climate-land-use combinations, quadrants were first classified into five climatic zones $(<7.5,7.5-8,8-8.5$, $8.5-9$ and $>9^{\circ} \mathrm{C}$ ) based on 30-year mean air temperature data (1$\mathrm{km}^{2}$ resolution) averaged for each quadrant (climatological reference period 1981-2010, Deutscher Wetterdienst, 2020). We further categorised each quadrant as one of three dominant regional land-use types based on proportional land use (CORINE, 2012; Table S1): near-natural quadrants (>85\% near-natural vegetation with a minimum of $50 \%$ forest), agricultural quadrants ( $>40 \%$ arable land and managed grassland) and urban quadrants ( $>14 \%$ housing, industry and traffic infrastructure). Due to the long history of anthropogenic land use, pristine native habitats are very rare in Bavaria $(<2 \%)$. Forests-mostly managed but permanent habitats-can therefore be considered as less disturbed than agricultural land with high pesticide pressure or urban areas with high levels of sealing. Accordingly, we merged forests, woodlands, nature protection areas and seminatural habitats (mostly calcareous grasslands and wetlands) in the category 'near-natural', and made sure a sufficient amount of forest $(>50 \%)$ was present in each 'near-natural' quadrant. Cut-off values for land use and climate were chosen to (a) maximise climatic differences and the contrast among land-use types, with anthropogenic impact ranging from low (near-natural) to very high (urban); (b) achieve equal intervals and a similar number of quadrants within each category; and (c) obtain enough quadrants in each class to realise an even distribution and meet logistic requirements (e.g. reduce travelling time, avoid no-fly zones for UAVs where aerial assessments were planned). Based on these prerequisites, we selected four quadrants of each of the 15 climate-land-use combinations (60 quadrants, i.e. study regions, Figures 2 and 3).

\subsection{2 | Step 2-Create heatmaps to reduce correlations among landscape variables}

Within each of the 60 quadrants, we aimed to investigate the impact of local land use and interactive effects of landscape-scale land use (composition and configuration) on biodiversity and ecosystem services. The landscape scale was hereby defined as $1-\mathrm{km}$ radius around local study plots, as this scale was shown to have ecological relevance for arthropods (Bosem Baillod et al., 2017; Holzschuh et al., 2016; Thies et al., 2003). As the strength of correlations among landscape variables depends on the location of local study plots, we implemented a novel heatmap approach with a priori knowledge of potential relationships (Figure 1). These correlation heatmapscreated for four dominant contrasting local land-use types identified within our quadrants-served as systematic criterion for local study plot selection by identifying potential sites with the lowest possible correlation between landscape composition and configuration (Figure 2).

The procedure to create these heatmaps involved the following steps: (1) Within each quadrant and starting $1 \mathrm{~km}$ away from the quadrant edge, we created a grid of $320 \mathrm{~m}$ resolution (resolution of the underlying CORINE data (2012), Figure 4a). We calculated four landscape composition variables (proportional cover of four local land-use types: forest, grassland, arable land, settlement) and one configuration variable (edge density, i.e. length of edges between all habitat types on a per unit area, $\mathrm{m} / \mathrm{ha}$ ) for a $1-\mathrm{km}$ radius buffer
FIGURE 3 Implementation of a full-factorial, stratified design crossing regional climate and land use in Bavaria, Southern Germany. Climate zones (a) were based on 30-year (1981-2010) mean air temperatures in each quadrant $\left(1:<7.5^{\circ} \mathrm{C}\right.$, 2: $7.5-8^{\circ} \mathrm{C}, 3: 8-8.5^{\circ} \mathrm{C}, 4: 8.5-9^{\circ} \mathrm{C}, 5$ : $>9^{\circ} \mathrm{C}$ ). For land use (b), we distinguished between near-natural quadrants (> $85 \%$ near-natural vegetation with a minimum of $50 \%$ forest), agricultural quadrants ( $>40 \%$ arable land and managed grassland), and urban quadrants ( $>14 \%$ housing, industry and traffic infrastructure). The final 60 quadrants (i.e. study regions, c) covered 15 climate-land-use combinations with four replicates each

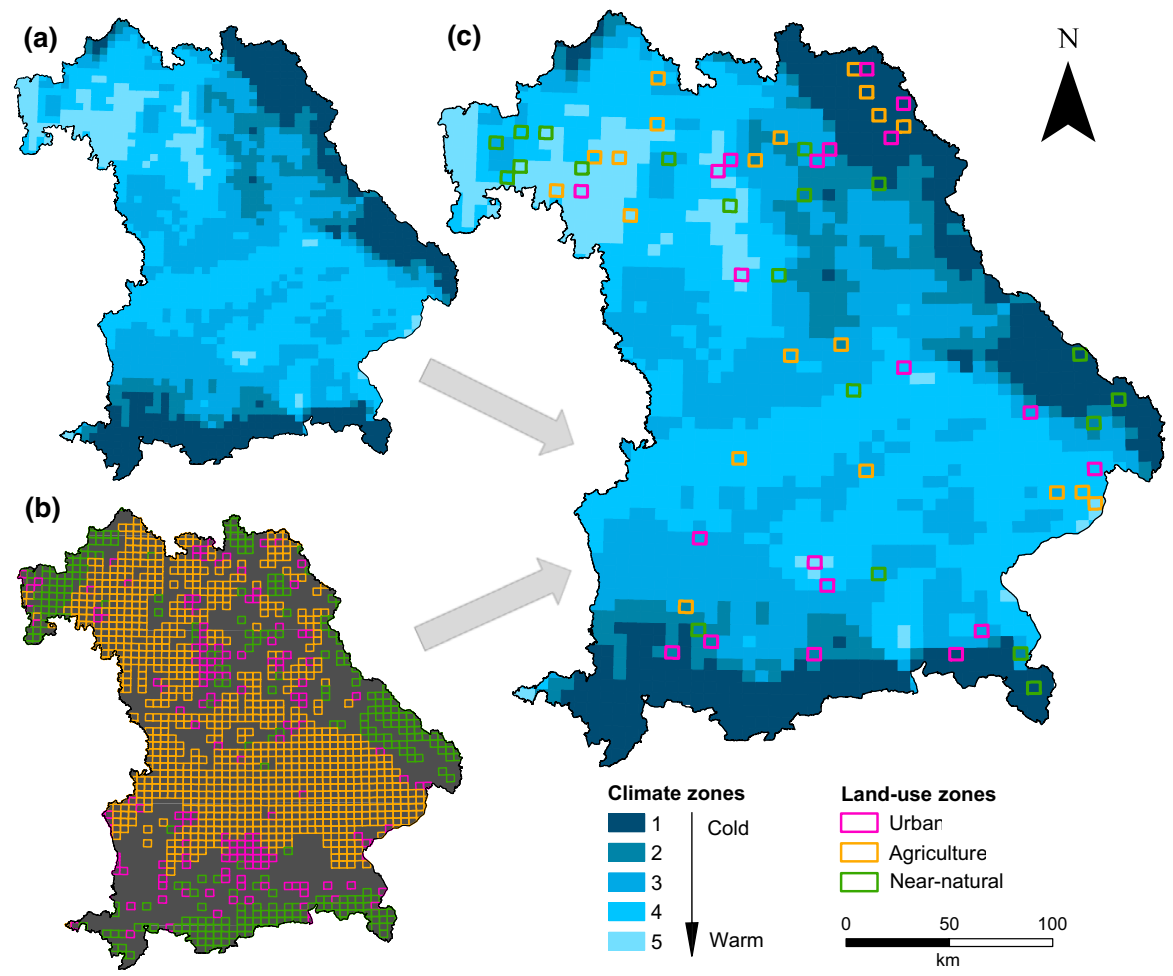


(a)

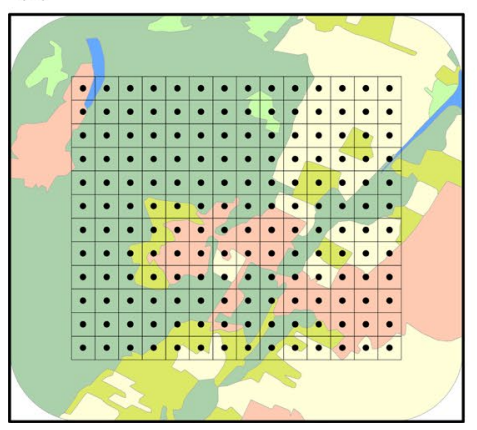

(b)

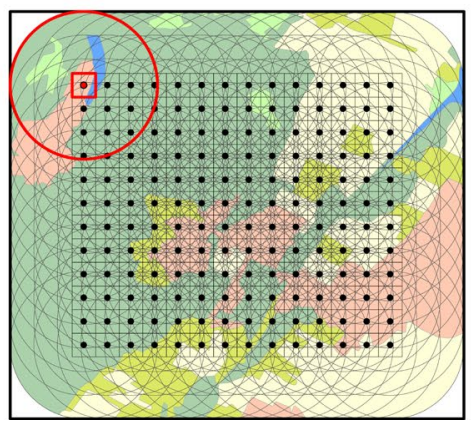

(c)

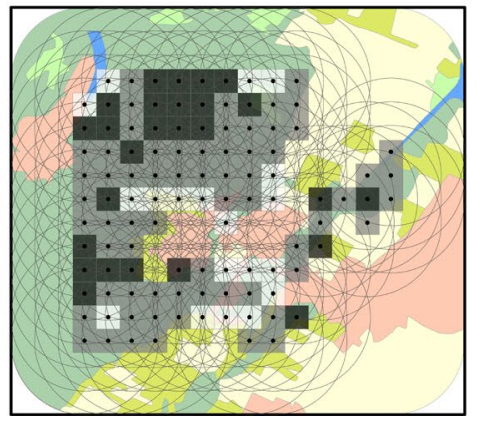

Land-use classes

Arable land

Forest

Grassland

Settlement

Semi-natural

Water

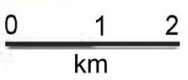

FIG URE 4 Process of deriving correlation heatmaps for each dominant land-use type to guide the selection of local study plots. Colours of polygons represent different land-use types (see classification in Table S1). Create a fishnet (a) of 320 m resolution inside each of 60 study quadrants (i.e. study regions). Calculate landscape composition and configuration within a 1-km radius around the centre of each $320 \times 320 \mathrm{~m}$ grid cell (b). Select grid cells dominated by the respective land-use type (here forest, dark green) and create land-use specific heatmaps of mean correlations between landscape composition and configuration based on 10,000 random selections of grid cells across all quadrants (c). Shades of grey in heatmaps indicate levels of the predicted degree of correlation (light $=$ high correlation, dark $=$ low correlation) if the respective grid was chosen

around the centre of each $320 \times 320 \mathrm{~m}$ grid cell (Figure $4 \mathrm{~b}$ ). Edge density was selected, because previous studies highlight its relevance for spillover and resource complementarity for biodiversity and ecosystem services (e.g. Martin et al., 2019). The next steps, here exemplified for forest, were repeated for each local land-use type. (2) We selected all grid cells (Figure 4c) with a proportional forest cover of $>20 \%$ (to accommodate a 0.5 -ha study plot and a $3 \times 30$ m experimental area) and $>5 \%$ forest in the surrounding $1-\mathrm{km}$ radius buffer (to ensure a minimum amount of forest was present in the surrounding landscape). (3) Of these forest grid cells and associated landscape buffers, we randomly chose one in each of the 60 study quadrants-if existent (quadrants without forest grids were excluded)-and calculated the overall Pearson's $r$ correlation coefficient between the surrounding landscape composition (here forest cover) and configuration (edge density) based on the random plot selection. (4) This random selection and calculation was repeated 10,000 times. (5) For each forest grid cell $i$ we then calculated the average Pearson's $\overline{r_{i}}$ coefficient across all the random combinations of points in which this cell was included:

$$
\overline{r_{i}}=\frac{\sum_{j=1}^{n} r_{i, j}}{n},
$$

where $r_{i, j}$ is the jth Pearson's $r$ coefficient resulting from random selection of that specific forest dominated grid cell $i$, and $n$ is the number of times that grid cell $i$ was included in one of the 10,000 random selections of points. And (6) in a last step and considering all forest grid cells in our 60 quadrants, we used natural breaks (Jenks natural breaks algorithm implemented in ArcMap v10.4) to classify the range of mean correlations into three categories to create the correlation heatmap for the local land-use type forest (Figure 4c). By repeating the steps described in (2-6) for all land-use types (forest, grassland, arable land, settlement), we derived a set of four heatmaps for each of the 60 quadrants. During the local plot selection process (Step 3), these heatmaps helped to reduce correlations of landscape composition and configuration around plots with specific land-use types (e.g. only forest plots), but also across all study plots.

\subsection{3 | Step 3-Selection of local study plots}

Within each quadrant, we aimed to establish local study plots of 0.5 ha size within contrasting land-use types (Figure 2). Although six main local land-use types had been identified during the heatmap process, two were neglected due to irrelevance for the project's scope (water) or as not available in sufficient quantity (semi-natural). Of the four dominant types (forest, grassland, arable land or settlement) not all were present in each quadrant. Therefore, we focused on three of the four dominant types per quadrant by considering availability (if only three types present) or regional dominance (three types with highest proportional cover) and contrast (whenever proportional cover of two land-use types was similar). We then used the respective heatmaps to preferentially place study plots in grid cells that had low predicted correlation values for the specific land-use type. We aimed to maximise the representativeness of land-use types by making predefined choices in plot selection: broadleaf was favoured over coniferous forests, intensive over extensive grasslands, conventional arable fields over organic or perennial fields and urban over rural settlements. To account for additional differences within habitats, we assessed local plant communities after plot establishment (vegetation surveys on seven subplots with a total of $10 \mathrm{~m}^{2}$ in 2019 and during transect walks in 200-m radius of sites in 2020). We also recorded local microclimatic variables (hourly measurements of temperature and humidity in $1.2 \mathrm{~m}$ height using thermologgers) to complement our long-term macroclimatic data, allow for acrossscale comparisons and assess the potential of specific land-use types to mitigate climate change impacts by creating microclimatic refugia. Further decision rules for plot selection included landowner permission, $>2 \mathrm{~km}$ between plots, $>50 \mathrm{~m}$ away from roads, 
water bodies and other land-use types, protection from vandalism and good accessibility. Nested within our large-scale factorial design, the resulting 180 plots allowed us to assess the influence of local land use on biodiversity and ecosystem services, while minimising correlations between landscape composition and configuration and accounting for microclimatic and structural differences.

\section{2 | Assessing efficiency of study design}

We assessed the efficiency of our stratified selection and heatmap approach by (a) region $(5.8 \times 5.8 \mathrm{~km})$ : calculating Pearson's $r$ correlation coefficients between regional climate and the proportion of our regional dominant land-use types near-natural, agriculture and urban; and (b) landscape (1-km radius): assessing relationships between local climate and the proportion of our dominant local landuse types forest, grassland, arable land and settlement. We also visually compared final correlation values between landscape composition and configuration with histograms of potential correlations resulting from 10,000 random selections.

The proportion of land-use types (region, landscape) and landscape composition and configuration variables were calculated in ArcGIS pro v2.2.0 and ArcMap v10.4 using CORINE data (2012). Climate data for regions and landscapes (mean air temperatures and associated precipitation amounts) were calculated using Esri ASCIl grid raster files with $1 \times 1 \mathrm{~km}$ resolution (Deutscher Wetterdienst, 2020) by averaging pixel values within each $5.8 \times 5.8 \mathrm{~km}$ quadrant and 1-km buffer around selected study plots, respectively. Although the land-use and climate variables presented here for the quadrant and 1-km scale were the basis for establishing our design, we also calculated these metrics at smaller and larger scales for different subprojects and depending on the biodiversity and ecosystem services under consideration (not shown). All Pearson's $r$ coefficients were calculated in R v4.0.2.

\section{3 | RESULTS}

\section{1 | Implementation of the experimental design}

Our design and selection process (Figure 2) allowed us to minimise the correlations between climate, land use and landscape metrics at multiple scales and resulted in an approximately even distribution of 60 quadrants (i.e. study regions) across Bavaria (Figure 3).

The regions stretched across extensive environmental gradients of temperature, precipitation and elevation, while covering large land-use gradients (Table 1). Regional land use (proportion of near-natural, agriculture and urban habitat) showed low correlations with regional mean temperatures (Figure $5 \mathrm{a}-\mathrm{c}$ ) and precipitation $(|r<0.3|$, Figure S1a-c).

For each quadrant, the heatmap procedure yielded four heatmaps (one each for the local land-use types forest, grassland, arable land and settlement), which were used to identify potential study plots within dominant local land-use types (Figure 6b-d). After ground-truthing of sites and gaining permission of landowners, three final plots were chosen per quadrant (Figure 6e), yielding 179 of 180 expected study plots (Figure 6a). One study plot was discarded as landowner permission was denied. Forest $(n=55)$ was the most selected local land-use type, followed by grassland $(n=46)$, arable land ( $n=43$ ) and settlement $(n=35)$.

On the landscape scale in 1-km radius around our study, the use of heatmaps during the site selection process helped us to achieve extensive, mostly uncorrelated spatial gradients of climate and land use (Table 1). Correlations of landscape-scale temperature and precipitation with composition variables (Figure $4 d-g$, Figure S1D-G) were low, as were correlations of both climate variables with edge density (temperature $r=-0.17$, precipitation $r=0.07$ ). The correlation between precipitation and temperature was moderately negative across plots ( $r=-0.51$ ), yet the microclimatic variables temperature and humidity, which were assessed throughout the study season, showed a low positive relationship $(r=0.32)$.

Compared to potential correlations based on the random selection of study plots (histograms of 10,000 random selections, Figure 7), the heatmap approach resulted in lower actual correlations (blue lines, Figure 7) between landscape composition and configuration in 1-km radius around study plots if plots were located in forest, arable land and settlements (Figure 7a,c,d). Only for grassland, the final correlation was positive and higher than predicted (Figure 7b). Taking all study plots independent of the local land-use type into account, this pattern was even stronger, with correlations between the proportion of habitats and edge density being very low for forest (Pearson's $r=-0.31$ ), arable land $(r=0.09)$ and settlement $(r=-0.08)$, yet high for grassland $(r=0.51)$ (red line, Figure 7 , Figure S2). Correlations among composition variables ranged from $r=-0.13$ (settlement and grassland) to -0.55 (arable land and forest).

This multi-scale GIS-supported study design is suited to disentangle climate and land-use effects on general and functional biodiversity and plant- or animal-based ecosystem services. In LandKlif, numerous add-on studies assess these relationships using a range of observational, empirical, modelling and survey data collected on different spatial scales (Table 2). The diversity of studies will allow us to investigate trade-offs between different measures of biodiversity and ecosystem services.

\section{4 | DISCUSSION}

Studies assessing the combined effects of land use and climate on biodiversity and ecosystem services commonly struggle with nonindependence of climate and land-use variables, restrictions in gradient range or scale and insufficient long-term datasets. Here, we present the protocol for a large-scale experimental design that aims to overcome these issues. While our basic design follows the selection principles for multi-scale landscape studies outlined in previous papers (Fahrig et al., 2011; Gillespie et al., 2017; Pasher et al., 2013), the use of a novel, automated heatmap approach and the inclusion of 
TAB LE 1 Summary statistics and description of climate and land-use variables on local, landscape and regional scale

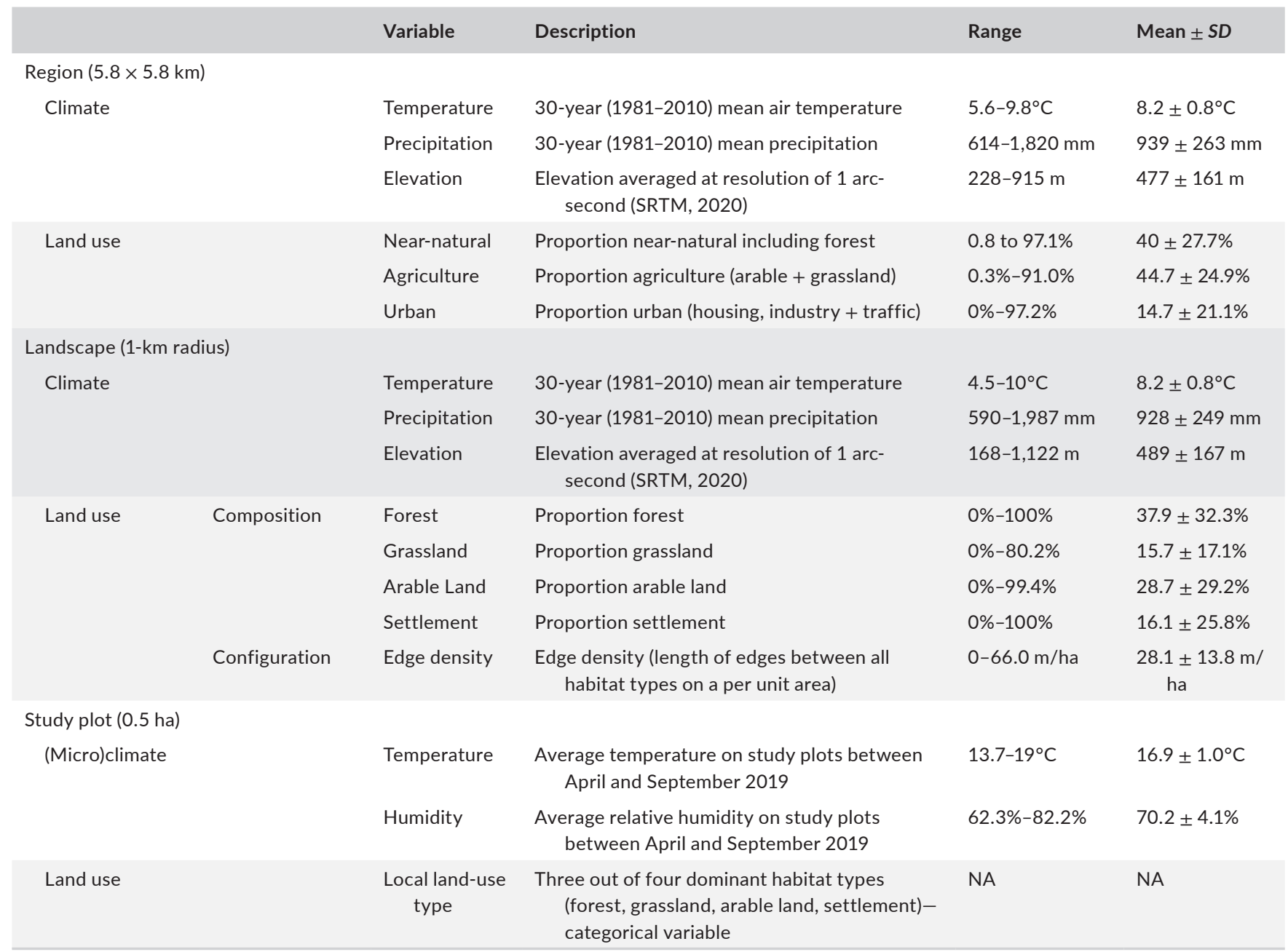

independent climatic gradients sets this design apart, both as baseline and space-for-time study.

First, the crossed and nested design resulted in relatively weak correlations between climate and land use at the regional $(|r|<0.33)$ and landscape scale $(|r|<0.29)$. The design also decoupled regional climate and land-use effects from the influence of small-scale land use due to the selection of three of four dominant local land-use types (forest, grassland, arable land or settlements) within our 60 quadrants (i.e. study regions). Regarding landscape composition and configuration in a 1-km radius around study plots, the heatmap approach lowered correlations compared to average potential correlations for specific local land-use types (blue lines, Figure 7), but these benefits were not that substantial in absolute terms (i.e. correlations for selected plots quite close to peak of distribution for random selection). However, there are three points to consider: (a) these actual correlations were based on a subset of plots (specific local land-use types), and were much lower for forest, arable land and settlement if calculated across all study plots (red lines, Figure 7), which is the gradient range primarily used for analysis in our project; (b) reducing landscape correlations may be difficult for land-use types such as forest, where patches generally occur clustered, causing higher negative correlations with edge density than for settlements or arable land. For grassland, correlations seem to be generally low, yet increased during the selection process, possibly due to inherent correlations among land-use types and nonlinear relationships between grassland amount and edge density in the landscape; and (c) in our project, complex private ownership structures, logistic and other constraints (e.g. transportation costs, time constraints, accessibility and permissions) prevented us from selecting combinations of study plots closer to $r=0$. Our method is situated halfway between two extremes: the blind selection of study plots that may inherently cause strong landscape correlations or requires the reduction in parameter space (see Figure 1) and choosing the best available random selection of plots during the process of creating heatmaps. Accordingly, the chance of moving towards low landscape correlations ultimately depends on the gradient range and land-use type considered and methodological, logistical and ownership constraints that may be lower in other studies.

Second, we increased the coverage of spatial scales and land-use types, thereby maximising the number of explanatory factors that can be analysed in parallel. Concurrently, our method of 'a priori' employing long-term climate data and extensive GIS-based exploration of potential study plots enabled us to cover independent, large climatic and land-use gradients. For landscape composition 


\section{Region (quadrant)}

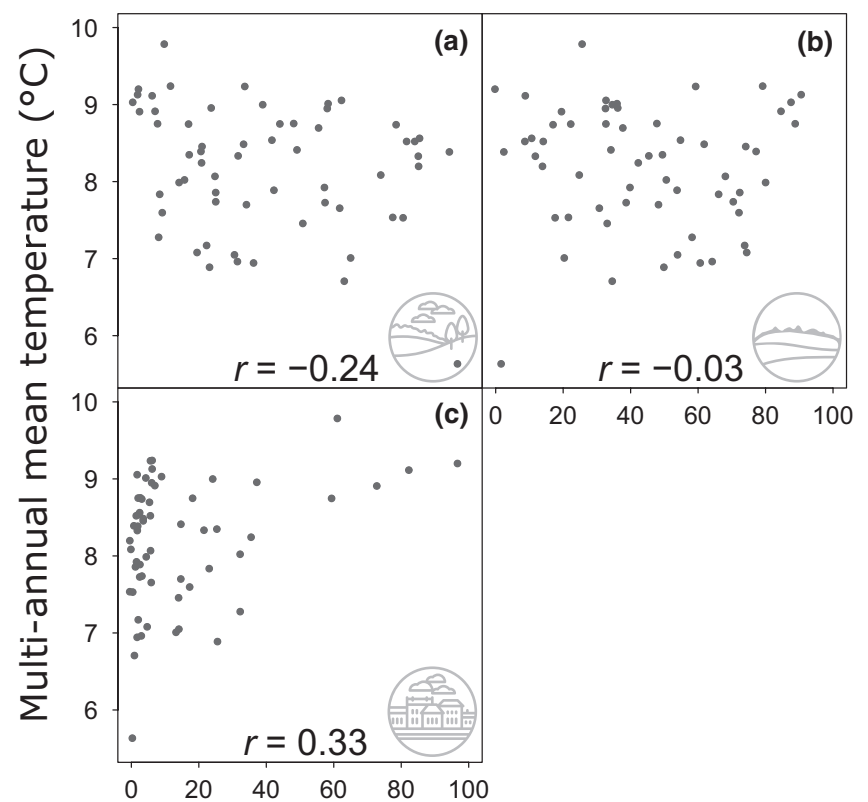

Landscape (around plot)

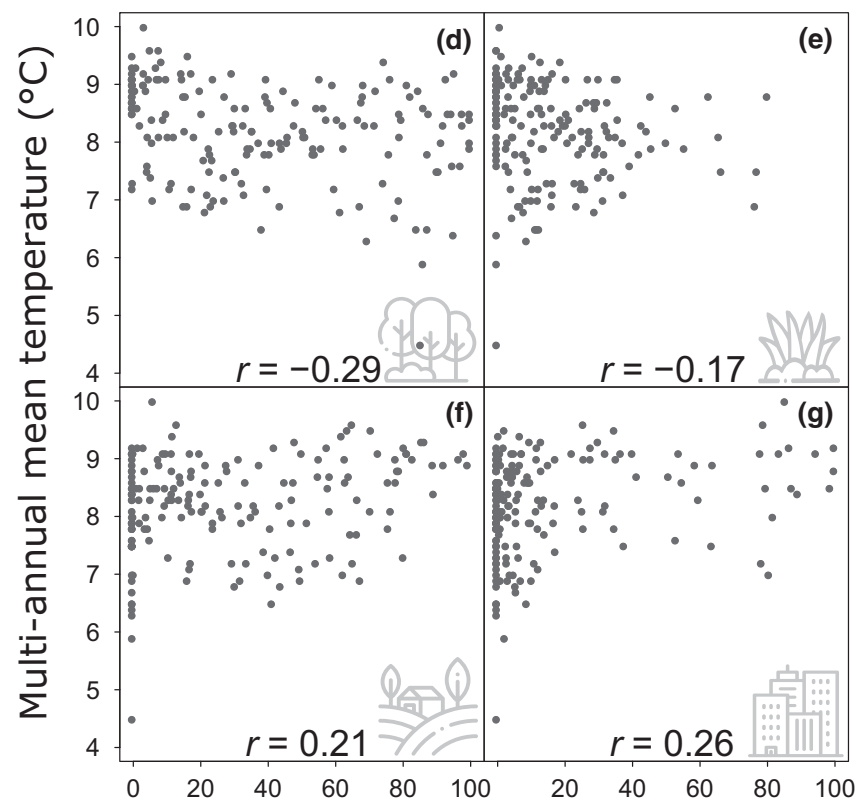

Proportion of land use (\%)

FIGURE 5 Relationships between 30-year mean temperatures (1981-2010) and proportional land cover (composition) for the regional land-use types near-natural (a), agriculture (b) and urban (c), and for the landscape-scale land-use types forest (d), grassland (e), arable land (f) and settlement (g). Pearson's $r$ coefficients based on 60 quadrants ( $5.8 \times 5.8 \mathrm{~km}$ study regions, a-c) and 179 (out of expected 180$)$ study plots (1-km radius around local study plots, $\mathrm{d}-\mathrm{g}$ )

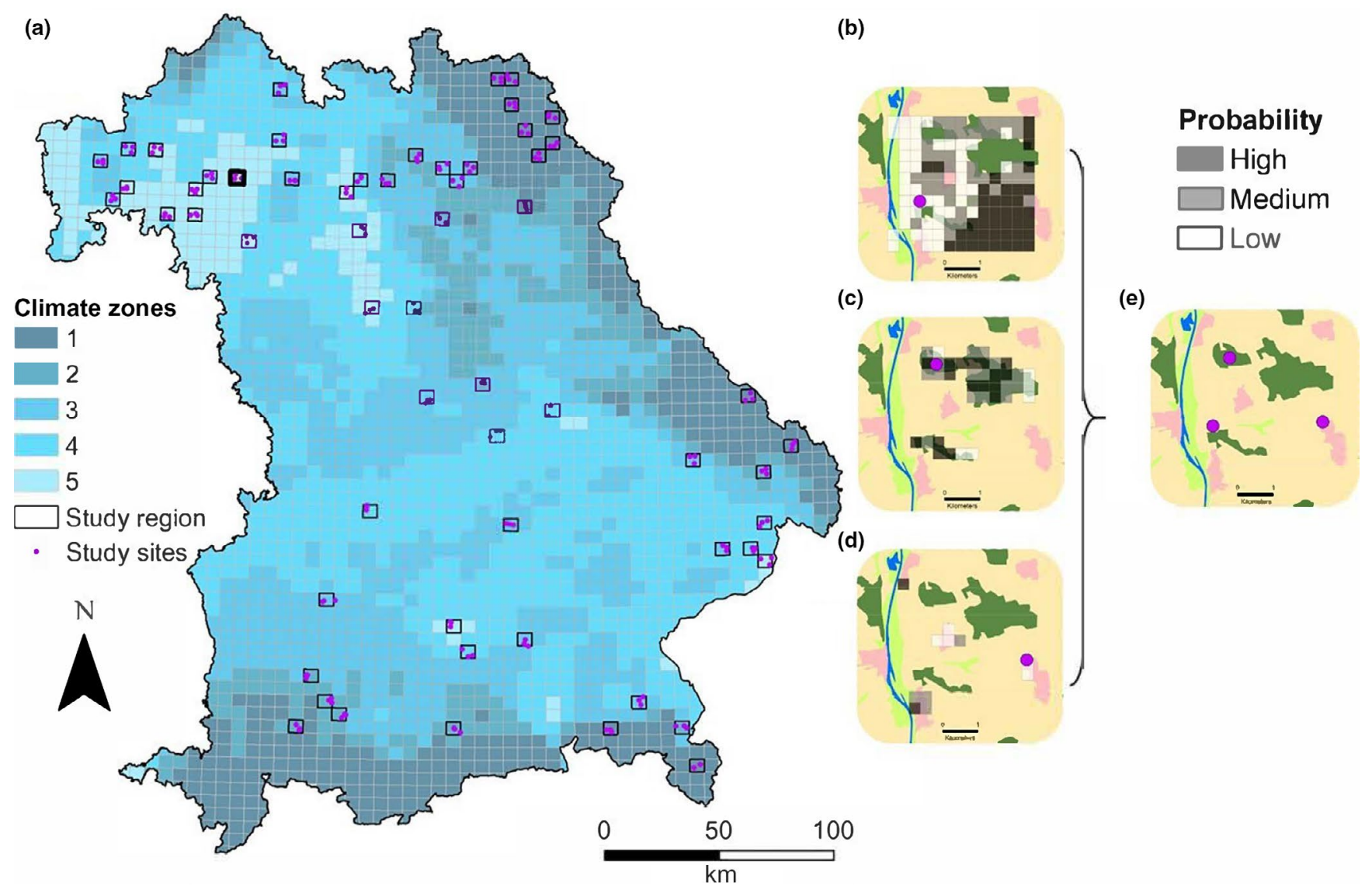

FIGURE 6 Map of all 179 (out of expected 180) study plots in 60 study regions (a) and example of heatmaps for three dominant local land-use types (arable land (b), forest (c), and settlement (d)) used for the final selection of study plots (e). Shades of grey in heatmaps indicate levels of the predicted degree of correlation (light $=$ high correlation, dark = low correlation) if the respective grid was chosen 


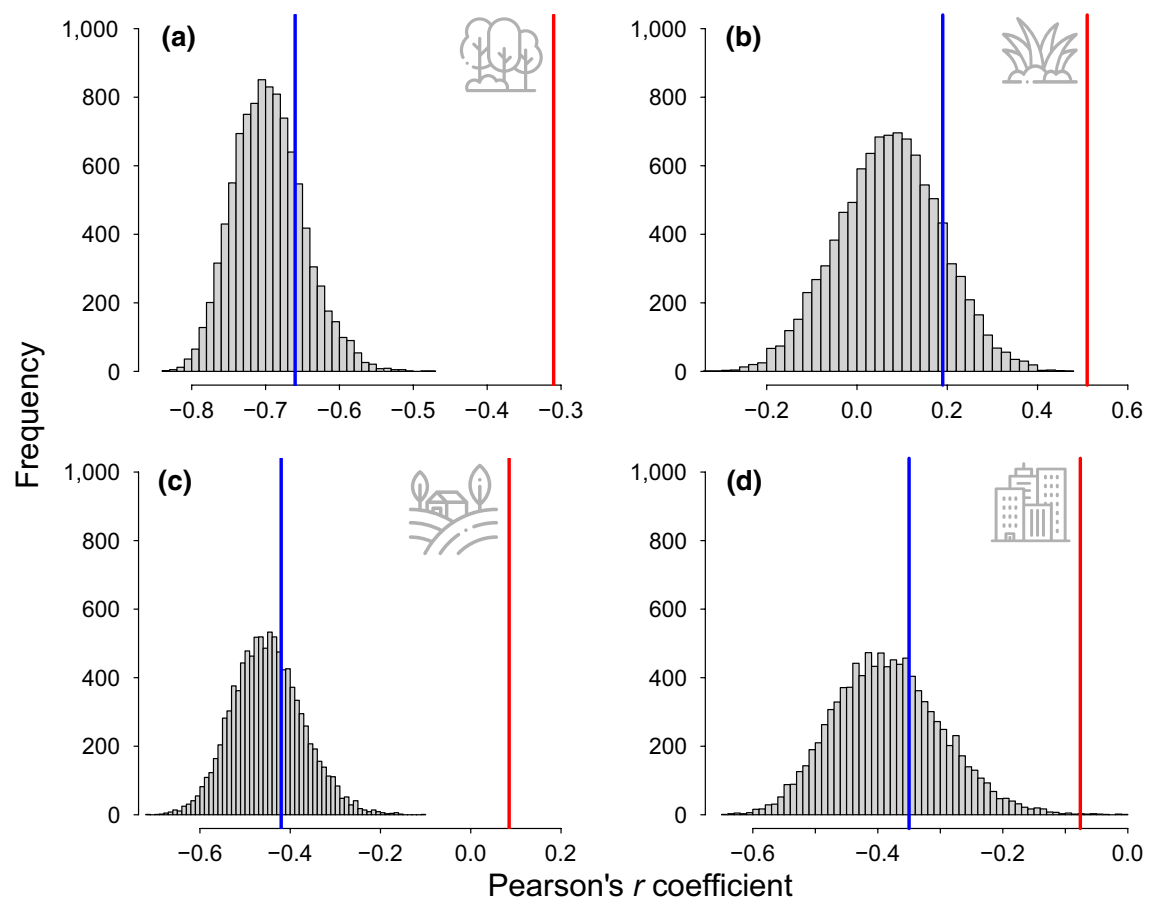

FIG URE 7 Potential and actual Pearson's $r$ correlations between landscape composition (proportional cover of land-use types) and configuration (edge density) in 1-km radius around study plots. Histograms (grey bars) show range of potential correlations resulting from 10,000 random selections of grid cells (i.e. potential study plots, cf. 'heatmap procedure'). Compared to those, actual correlations (blue lines) between edge density and the proportion of forest $(n=55$; a), arable land $(n=43 ; c)$ and settlement $(n=35$; d) were lower than expected for the final selection of plots if only considering plots within the same land-use type as at the landscape scale (e.g. only forest plots for a). For grassland plots, the actual correlation between grassland proportion and edge density was higher than expected ( $n=46$; b). Red lines show actual correlations among edge density and land-use specific composition variables across all selected study plots, independent of local habitat type $(n=179)$

and configuration of the full set of 179 final study plots, our data highlight the natural, unimodal relationship between these variables, which is most pronounced for forest cover and grows weaker from grassland to arable land and settlement, with peaks between $40 \%$ and 60\% land cover (Appendix S2). This implies that studies covering narrow landscape gradients between $0 \%-50 \%$ and $50 \%-100 \%$ may observe contrasting positive or negative correlations between these landscape variables, respectively, while studies focussed on intermediate landscape gradients are most likely to reduce the correlation between variables and differentiate between individual effects, which may be impossible at the extreme ends of the spectrum.

Finally, our extensive on-field assessments within this experimental framework will fill existing knowledge gaps about biodiversity trends across taxa, relationships between above- and below-ground arthropods and the microbial diversity of decomposer communities. For instance, the current design allowed us to detect contrasting responses of total flying insect biomass and richness to land use and climate (Uhler et al., 2021). Yet the proposed method can also easily be extended to include higher resolution land-use types or detailed landscape structures ecologically relevant for specific target organisms. We can also assess potential trade-offs among ecosystem service provisioning and current and predicted interactive effects of climate and land use on biodiversity-ecosystem functioning relationships. In this context, the implemented space-for-time approach has crucial advantages over time series. Recently established longterm biodiversity monitoring schemes will not yield meaningful results before several decades, which may be too late considering the current speed of global change. Furthermore, long-term climatic change often goes hand in hand with land-use change, making it difficult to disentangle individual effects (Dale, 1997). In addition, issues such as shifting baselines or phenologies, bias in site selection and detection may cause misleading results in time-series analysis (Didham et al., 2020). Other methods, such as large-scale, manipulative climate-land-use experiments following the idea of $\mathrm{BACl}$ designs (Before-After-Control-Impact studies, Christie et al., 2019) are highly interesting but almost impossible to implement. While large-scale factorial experiments can be used to cancel out environmental noise that may override ecosystem responses to global change (Schädler et al., 2019), implementation costs are high and the required block set-up on relatively small spatial scales is unsuitable for assessing effects on mobile organisms such as pollinators or mammals.

Space-for-time approaches also have limitations. For instance, other drivers of biodiversity, such as anthropogenic pressure or altered biotic interactions, may mask the response to climate, especially if only small spatial scales (a few kilometres or less) with small climatic differences are considered (Blois et al., 2013). Similarly, time-lags in the response of biodiversity to either climate or land 
TAB LE 2 Example for assessments of biodiversity (yellow), ecosystem services (green) and socio-economic/management information ('other', blue) in the LandKlif project used to investigate relationships with climate and land use. Observational and empirical data were collected on up to 179 study plots in 2019 and 2020 and complemented with modelling approaches and stakeholder surveys. Extended categorisation of ecosystem services based on TEEB (2010) and Rabe et al. (2016)

\begin{tabular}{|c|c|c|c|}
\hline & Group/service & Detail & Scale \\
\hline \multirow{2}{*}{ Biodiversity } & Microbes & Soil/decomposer microbial diversity & Plot \\
\hline & Arthropods & $\begin{array}{l}\text { Total biomass and richness of flying and crawling arthropods; } \\
\text { functional abundance and richness of arthropod } \\
\text { decomposers, pollinators, trap-nesting Hymenoptera, pests } \\
\text { and predators }\end{array}$ & Plot \\
\hline \multirow[t]{9}{*}{ Ecosystem services } & Pest regulation ${ }^{*}$ & Predation and parasitism rate, herbivory & Plot \\
\hline & Decomposition ${ }^{*}$ & Decomposition of deadwood, carrion and dung & Plot \\
\hline & Pollination & Seed set (yield); pollination services; flower resource availability & Plot/Region \\
\hline & Food & Crop biomass and yield, game & Plot/Region \\
\hline & Erosion prevention & Wind/water erosion prevention (e.g. vegetation cover) & Region \\
\hline & Regulation of water flows & Groundwater recharge & \\
\hline & (Micro)Climate regulation & Net productivity; carbon storage & Plot/Bavaria \\
\hline & Moderation of extreme events & Flood control (soil infiltration, vegetation cover, topography) & Region \\
\hline & Water treatment & Water quality regulation (nitrogen and phosphorus retention) & Region \\
\hline \multirow[t]{3}{*}{ Other } & Stakeholder preferences & Preferences for ecosystem services & Region \\
\hline & Stakeholder perceptions & Climate change perceptions & Region \\
\hline & Landowner management & Management of land and crop fields used for experiments & Plot \\
\hline
\end{tabular}

*Additional ecosystem services assessed.

use may reduce the accuracy of space-for-time studies compared to long-term time series (Banet \& Trexler, 2013). In contrast, data obtained from spatial observations were shown to overestimate phenology responses to temperature compared to long-term phenological data (Jochner et al., 2013). Still, space-for-time substitutions based on the largest possible climatic gradient are a useful and fast alternative to gain important, policy-relevant insights into the interactive effects of climate and land-use change on biodiversity and ecosystem services. They also complement long-term studies by highlighting more general patterns. By utilising the full parameter space of the climatic and landscape variables assessed here (Figure 1), we enhanced the validity of space-for-time substitutions related to climate change (Blois et al., 2013). We further reduced the chance of observing misleading findings in cases where nonmonotonic relationships cause contradictory relationships between environmental variables and biodiversity if only a narrow variable range is used (Eigenbrod et al., 2011).

\section{5 | CONCLUSIONS}

Our multi-scale study protocol expands on previous designs which addressed local gradients in climate and land use (Peters et al., 2019) or gradients in landscape structure in multiple regions (Gillespie et al., 2017; Holzschuh et al., 2016). It allows to evaluate scaledependent and interactive effects of current climate and land-use gradients on biodiversity and ecosystem services, thereby highlighting landscape management schemes with the potential to mitigate adverse effects of climate change. Similarly, the assessment of a large diversity of ecosystem responses identifies high-risk groups and trade-offs between different aspects of biodiversity and ecosystem services, as well as land-use types and scales particularly prone to face negative climate change impacts. The observed relationships can then be used to parameterise and validate climateland-use models, which help to predict long-term responses to climate change. Furthermore, our design provides valuable baseline data to assess the effectiveness of future restoration measures at local, landscape and regional scales. We believe that this approach of an objective, multi-scale site selection across large regions deserves consideration in the implementation of national and European longterm ecosystem monitoring schemes.

\section{ACKNOWLEDGEMENTS}

Icons used in graphs made by Freepik (http://www.flaticon.com/). CORINE Land Cover (CLC) provided by the European Union, European Environment Agency (EEA) under the framework of 
the Copernicus programme. Climate data provided by Deutscher Wetterdienst (DWD). This study was conducted within the framework of the joint project Landklif (https://www.landklif.biozentrum. uni-wuerzburg.de/) funded by the Bavarian Ministry of Science and the Arts via the Bavarian Climate Research Network (bayklif). Open access funding enabled and organised by Projekt DEAL.

\section{CONFLICT OF INTEREST}

The authors declare no conflict of interest.

\section{AUTHORS' CONTRIBUTIONS}

S.R., J.Z., J.M., T.H. and I.S.-D. conceived the ideas and designed the methodology; J.Z. and C.K.-F. collected the data; S.R. and J.Z. analysed the data; S.R., J.Z. and I.S.-D. led the writing of the manuscript. All authors contributed critically to the drafts and gave final approval for publication.

\section{PEER REVIEW}

The peer review history for this article is available at https://publo ns.com/publon/10.1111/2041-210X.13759.

\section{DATA AVAILABILITY STATEMENT}

All data and R code are available at Dryad Digital Repository https:// doi.org/10.5061/dryad.np5hqbzv1 (Redlich et al., 2021).

\section{ORCID}

Sarah Redlich iD https://orcid.org/0000-0001-5609-0576 Caryl Benjamin iD https://orcid.org/0000-0002-1704-4216 Maninder Singh Dhillon (iD https://orcid.org/0000-0002-2351-9492 Jana Englmeier (iD https://orcid.org/0000-0002-0559-1618 Jörg Ewald (iD https://orcid.org/0000-0002-2758-9324 Ute Fricke (iD https://orcid.org/0000-0002-5284-4518 Cristina Ganuza iD https://orcid.org/0000-0002-4197-1829 Thomas Hovestadt iD https://orcid.org/0000-0001-7368-6013 Johannes Kollmann iD https://orcid.org/0000-0002-4990-3636 Thomas Koellner (iD https://orcid.org/0000-0001-5022-027X Carina Kübert-Flock iD https://orcid.org/0000-0003-0708-5863 Harald Kunstmann iD https://orcid.org/0000-0001-9573-1743 Annette Menzel iD https://orcid.org/0000-0002-7175-2512 Wibke Peters (iD https://orcid.org/0000-0002-7105-428X Rebekka Riebl (D) https://orcid.org/0000-0002-8218-4717 Thomas Rummler iD https://orcid.org/0000-0001-7765-2275 Sandra Rojas-Botero (iD https://orcid.org/0000-0002-0366-7383 Cynthia Tobisch iD https://orcid.org/0000-0002-2039-1462 Johannes Uhler (iD https://orcid.org/0000-0003-3022-1229 Jörg Müller iD https://orcid.org/0000-0002-1409-1586 Ingolf Steffan-Dewenter (iD https://orcid. org/0000-0003-1359-3944

\section{REFERENCES}

Banet, A. I., \& Trexler, J. C. (2013). Space-for-time substitution works in Everglades ecological forecasting models. PLoS ONE, 8(11), e81025. https://doi.org/10.1371/journal.pone.0081025
Bayerisches Landesamt für Statistik. (2020). Statistics. Retrieved from https://www.statistik.bayern.de/

Blois, J. L., Williams, J. W., Fitzpatrick, M. C., Jackson, S. T., \& Ferrier, S. (2013). Space can substitute for time in predicting climatechange effects on biodiversity. Proceedings of the National Academy of Sciences of the United States of America, 110(23), 9374-9379. https://doi.org/10.1073/pnas.1220228110

Bosem Baillod, A., Tscharntke, T., Clough, Y., \& Batáry, P. (2017). Landscapescale interactions of spatial and temporal cropland heterogeneity drive biological control of cereal aphids. Journal of Applied Ecology, 54(6), 1804-1813. https://doi.org/10.1111/1365-2664.12910

Brummitt, N. A., Bachman, S. P., Griffiths-Lee, J., Lutz, M., Moat, J. F., Farjon, A., Donaldson, J. S., Hilton-Taylor, C., Meagher, T. R., Albuquerque, S., Aletrari, E., Andrews, A. K., Atchison, G., Baloch, E., Barlozzini, B., Brunazzi, A., Carretero, J., Celesti, M., Chadburn, H., ... Nic Lughadha, E. M. (2015). Green plants in the red: A baseline global assessment for the IUCN Sampled Red List Index for Plants. PLoS ONE, 10(8), e0135152. https://doi.org/10.1371/journ al.pone.0135152

Chaplin-Kramer, R., Sharp, R. P., Weil, C., Bennett, E. M., Pascual, U., Arkema, K. K., Brauman, K. A., Bryant, B. P., Guerry, A. D., Haddad, N. M., Hamann, M., Hamel, P., Johnson, J. A., Mandle, L., Pereira, H. M., Polasky, S., Ruckelshaus, M., Shaw, M. R., Silver, J. M., ... Daily, G. C. (2019). Global modeling of nature's contributions to people. Science, 366(6462), 255-258. https://doi.org/10.1126/scien ce.aaw3372

Christie, A. P., Amano, T., Martin, P. A., Shackelford, G. E., Simmons, B. I., \& Sutherland, W. J. (2019). Simple study designs in ecology produce inaccurate estimates of biodiversity responses. Journal of Applied Ecology, 56(12), 2742-2754. https://doi. org/10.1111/1365-2664.13499

CORINE. (2012). Copernicus land monitoring service 2012, European Environment Agency. Retrieved from https://land.copernicus.eu/ pan-european/corine-land-cover/clc-2012

Dainese, M., Martin, E. A., Aizen, M. A., Albrecht, M., Bartomeus, I., Bommarco, R., Carvalheiro, L. G., Chaplin-Kramer, R., Gagic, V., Garibaldi, L. A., Ghazoul, J., Grab, H., Jonsson, M., Karp, D. S., Kennedy, C. M., Kleijn, D., Kremen, C., Landis, D. A., Letourneau, D. K., ... Steffan-Dewenter, I. (2019). A global synthesis reveals biodiversity-mediated benefits for crop production. Science Advances, 5(10), eaax0121. https://doi.org/10.1126/sciadv.aax0121

Dale, V. H. (1997). The relationship between land-use change and climate change. Ecological Applications, 7(3), 753-769. https://doi. org/10.1890/1051-0761(1997)007[0753:TRBLUC]2.0.CO;2

Deutscher Wetterdienst. (2020). DWD Climate Data Center (CDC): Multiannual means of grids of precipitation and air temperature $(2 \mathrm{~m})$ over Germany from 1981-2010, version v1.0. Retrieved from https:// opendata.dwd.de

Díaz, S., Settele, J., Brondízio, E., Ngo, H., Guèze, M., Agard, J., Arneth, A., Balvanera, P., Brauman, K., Butchart, S., Chan, K., Garibaldi, L., Ichii, K., Liu, J., Subrmanian, S., Midgley, G., Miloslavich, P., Molnár, Z., Obura, D., ... Zayas, C. (2019). Summary for policymakers of the global assessment report on biodiversity and ecosystem services of the Intergovernmental Science-Policy Platform on Biodiversity and Ecosystem Services. Secretariat of the Intergovernmental SciencePolicy Platform on Biodiversity and Ecosystem Services.

Didham, R. K., Basset, Y., Collins, C. M., Leather, S. R., Littlewood, N. A., Menz, M. H. M., Müller, J., Packer, L., Saunders, M. E., Schönrogge, K., Stewart, A. J. A., Yanoviak, S. P., \& Hassall, C. (2020). Interpreting insect declines: Seven challenges and a way forward. Insect Conservation and Diversity, 13(2), 103-114. https:// doi.org/10.1111/icad.12408

Dirzo, R., Young, H. S., Galetti, M., Ceballos, G., Isaac, N. J. B., \& Collen, B. (2014). Defaunation in the Anthropocene. Science, 345(6195), 401406. https://doi.org/10.1126/science.1251817 
Duffy, J. E., Godwin, C. M., \& Cardinale, B. J. (2017). Biodiversity effects in the wild are common and as strong as key drivers of productivity. Nature, 549(7671), 261-264. https://doi.org/10.1038/nature23886

Eigenbrod, F., Hecnar, S. J., \& Fahrig, L. (2011). Sub-optimal study design has major impacts on landscape-scale inference. Biological Conservation, 144(1), 298-305. https://doi.org/10.1016/j. biocon.2010.09.007

Estrada, A., Morales-Castilla, I., Caplat, P., \& Early, R. (2016). Usefulness of species traits in predicting range shifts. Trends in Ecology \& Evolution, 31, 190-203. https://doi.org/10.1016/j.tree.2015.12.014

Fahrig, L., Baudry, J., Brotons, L., Burel, F. G., Crist, T. O., Fuller, R. J., Sirami, C., Siriwardena, G. M., \& Martin, J.-L. (2011). Functional landscape heterogeneity and animal biodiversity in agricultural landscapes. Ecology Letters, 14(2), 101-112. https://doi. org/10.1111/j.1461-0248.2010.01559.x

Foley, J. A., DeFries, R., Asner, G. P., Barford, C., Bonan, G., Carpenter, S R., Chapin, F. S., Coe, M. T., Daily, G. C., Gibbs, H. K., Helkowski, J. H., Holloway, T., Howard, E. A., Kucharik, C. J., Monfreda, C., Patz, J. A., Prentice, I. C., Ramankutty, N., \& Snyder, P. K. (2005). Global consequences of land use. Science, 309(5734), 570-574. https:// doi.org/10.1126/science.1111772

Fourcade, Y., WallisDeVries, M. F., Kuussaari, M., van Swaay, C. A. M., Heliölä, J., \& Öckinger, E. (2021). Habitat amount and distribution modify community dynamics under climate change. Ecology Letters, 24(5), 950-957. https://doi.org/10.1111/ele.13691

Fox, R., Oliver, T. H., Harrower, C., Parsons, M. S., Thomas, C. D., \& Roy, D. B. (2014). Long-term changes to the frequency of occurrence of British moths are consistent with opposing and synergistic effects of climate and land-use changes. Journal of Applied Ecology, 51(4), 949-957. https://doi.org/10.1111/1365-2664.12256

Gillespie, M. A. K., Baude, M., Biesmeijer, J., Boatman, N., Budge, G. E., Crowe, A., Memmott, J., Morton, R. D., Pietravalle, S., Potts, S. G., Senapathi, D., Smart, S. M., \& Kunin, W. E. (2017). A method for the objective selection of landscape-scale study regions and sites at the national level. Methods in Ecology and Evolution, 8(11), 14681476. https://doi.org/10.1111/2041-210X.12779

Hallmann, C. A., Sorg, M., Jongejans, E., Siepel, H., Hofland, N., Schwan, H., Stenmans, W., Müller, A., Sumser, H., Hörren, T., Goulson, D., \& de Kroon, H. (2017). More than 75 percent decline over 27 years in total flying insect biomass in protected areas. PLoS ONE, 12(10), e0185809. https://doi.org/10.1371/journal.pone.0185809

Harrison, S. (2020). Plant community diversity will decline more than increase under climatic warming. Philosophical Transactions of the Royal Society B: Biological Sciences, 375(1794), 20190106. https:// doi.org/10.1098/rstb.2019.0106

Holzschuh, A., Dainese, M., González-Varo, J. P., Mudri-Stojnić, S., Riedinger, V., Rundlöf, M., Scheper, J., Wickens, J. B., Wickens, V. J., Bommarco, R., Kleijn, D., Potts, S. G., Roberts, S. P. M., Smith, H. G., Vilà, M., Vujić, A., \& Steffan-Dewenter, I. (2016). Massflowering crops dilute pollinator abundance in agricultural landscapes across Europe. Ecology Letters, 19(10), 1228-1236. https:// doi.org/10.1111/ele.12657

Jochner, S., Caffarra, A., \& Menzel, A. (2013). Can spatial data substitute temporal data in phenological modelling? A survey using birch flowering. Tree Physiology, 33(12), 1256-1268. https://doi.org/10.1093/ treephys/tpt079

Laux, P., Nguyen, P. N. B., Cullmann, J., Van, T. P., \& Kunstmann, H. (2017). How many RCM ensemble members provide confidence in the impact of land-use land cover change? International Journal of Climatology, 37(4), 2080-2100. https://doi.org/10.1002/joc.4836

Martin, E. A., Dainese, M., Clough, Y., Báldi, A., Bommarco, R., Gagic, V., Garratt, M. P. D., Holzschuh, A., Kleijn, D., Kovács-Hostyánszki, A., Marini, L., Potts, S. G., Smith, H. G., Al Hassan, D., Albrecht, M., Andersson, G. K. S., Asís, J. D., Aviron, S., Balzan, M. V., ... SteffanDewenter, I. (2019). The interplay of landscape composition and configuration: New pathways to manage functional biodiversity and agroecosystem services across Europe. Ecology Letters, 22(7), 1083-1094. https://doi.org/10.1111/ele.13265

Mori, A. S., Isbell, F., \& Seidl, R. (2018). $\beta$-diversity, community assembly, and ecosystem functioning. Trends in Ecology \& Evolution, 33(7), 549-564. https://doi.org/10.1016/j.tree.2018.04.012

Newbold, T., Hudson, L. N., Hill, S. L. L., Contu, S., Lysenko, I., Senior, R. A., Börger, L., Bennett, D. J., Choimes, A., Collen, B., Day, J., De Palma, A., Díaz, S., Echeverria-Londoño, S., Edgar, M. J., Feldman, A., Garon, M., Harrison, M. L. K., Alhusseini, T., ... Purvis, A. (2015). Global effects of land use on local terrestrial biodiversity. Nature, 520(7545), 45-50. https://doi.org/10.1038/nature14324

Parmesan, C. (2006). Ecological and evolutionary responses to recent climate change. Annual Review of Ecology, Evolution, and Systematics, 37(1), 637-669. https://doi.org/10.1146/annurev.ecols ys.37.091305.110100

Pasher, J., Mitchell, S. W., King, D. J., Fahrig, L., Smith, A. C., \& Lindsay, K. E. (2013). Optimizing landscape selection for estimating relative effects of landscape variables on ecological responses. Landscape Ecology, 28(3), 371-383. https://doi.org/10.1007/s1098 0-013-9852-6

Peters, M. K., Hemp, A., Appelhans, T., Becker, J. N., Behler, C., Classen, A., Detsch, F., Ensslin, A., Ferger, S. W., Frederiksen, S. B., Gebert, F., Gerschlauer, F., Gütlein, A., Helbig-Bonitz, M., Hemp, C., Kindeketa, W. J., Kühnel, A., Mayr, A. V., Mwangomo, E., ... Steffan-Dewenter, I. (2019). Climate-land-use interactions shape tropical mountain biodiversity and ecosystem functions. Nature, 568(7750), 88-92. https://doi.org/10.1038/s41586-019-1048-z

Piano, E., Souffreau, C., Merckx, T., Baardsen, L. F., Backeljau, T., Bonte, D., Brans, K. I., Cours, M., Dahirel, M., Debortoli, N., Decaestecker, E., De Wolf, K., Engelen, J. M. T., Fontaneto, D., Gianuca, A. T., Govaert, L., Hanashiro, F. T. T., Higuti, J., Lens, L., ... Hendrickx, F. (2020). Urbanization drives cross-taxon declines in abundance and diversity at multiple spatial scales. Global Change Biology, 26(3), 1196-1211. https://doi.org/10.1111/gcb.14934

Provost, G. L., Badenhausser, I., Bagousse-Pinguet, Y. L., Clough, Y., Henckel, L., Violle, C., Bretagnolle, V., Roncoroni, M., Manning, P., \& Gross, N. (2020). Land-use history impacts functional diversity across multiple trophic groups. Proceedings of the National Academy of Sciences of the United States of America, 117(3), 1573-1579. https://doi.org/10.1073/pnas.1910023117

Rabe, S.-E., Koellner, T., Marzelli, S., Schumacher, P., \& Grêt-Regamey, A. (2016). National ecosystem services mapping at multiple scalesThe German exemplar. Ecological Indicators, 70, 357-372. https:// doi.org/10.1016/j.ecolind.2016.05.043

Redlich, S., Martin, E. A., \& Steffan-Dewenter, I. (2018). Landscape-level crop diversity benefits biological pest control. Journal of Applied Ecology, 55(5), 2419-2428. https://doi. org/10.1111/1365-2664.13126

Redlich, S., Zhang, J., Benjamin, C., Singh Dhillon, M., Englmeier, J., Ewald, J., Fricke, U., Ganuza, C., Haensel, M., Hovestadt, T., Kollmann, J., Koellner, T., Kübert-Flock, C., Kunstmann, H., Menzel, A., Moning, C., Peters, W., Riebl, R., Rummler, T., ... Steffan-Dewenter, I. (2021). Data from: Disentangling effects of climate and land use on biodiversity and ecosystem services at multiple scales-Protocol for a large-scale experimental design. Dryad Digital Repository, https:// doi.org/10.5061/dryad.np5hqbzv1

Rillig, M. C., Ryo, M., Lehmann, A., Aguilar-Trigueros, C. A., Buchert, S., Wulf, A., Iwasaki, A., Roy, J., \& Yang, G. (2019). The role of multiple global change factors in driving soil functions and microbial biodiversity. Science, 366(6467), 886-890. https://doi.org/10.1126/ science.aay2832

Schädler, M., Buscot, F., Klotz, S., Reitz, T., Durka, W., Bumberger, J., Merbach, I., Michalski, S. G., Kirsch, K., Remmler, P., Schulz, E., \& Auge, H. (2019). Investigating the consequences of climate change 
under different land-use regimes: A novel experimental infrastructure. Ecosphere, 10(3), e02635. https://doi.org/10.1002/ecs2.2635

Seibold, S., Gossner, M. M., Simons, N. K., Blüthgen, N., Müller, J., Ambarlı, D., Ammer, C., Bauhus, J., Fischer, M., Habel, J. C., Linsenmair, K. E., Nauss, T., Penone, C., Prati, D., Schall, P., Schulze, E.-D., Vogt, J., Wöllauer, S., \& Weisser, W. W. (2019). Arthropod decline in grasslands and forests is associated with landscape-level drivers. Nature, 574(7780), 671-674. https://doi.org/10.1038/s41586-019-1684-3

SRTM. (2020). Digital elevation-Shuttle Radar Topography Mission (SRTM) 1 Arc-Second. https://doi.org/10.5066/TEEBF7PR7TFT

TEEB. (2010). The economics of ecosystems and biodiversity. Ecological and economic foundations (P. Kumar, Ed.). Earthscan.

Thies, C., Steffan-Dewenter, I., \& Tscharntke, T. (2003). Effects of landscape context on herbivory and parasitism at different spatial scales. Oikos, 101(1), 18-25. https://doi.org/10.1034/j.1600-0706.2003.12567.x

Uhler, J., Redlich, S., Zhang, J., Hothorn, T., Tobisch, C., Ewald, J., Thorn, S., Seibold, S., Mitesser, O., Morinière, J., Bozicevic, V., Benjamin, C. S., Englmeier, J., Fricke, U., Ganuza, C., Haensel, M., Riebl, R., Rojas Botero, S., Rummler, T., ... Müller, J. (2021). Relationships of insect biomass and richness with land use along a climate gradient. Nature Communications, 12(1), 5946. https://doi.org/10.1038/s41467-021-26181-3

Urban, M. C. (2015). Accelerating extinction risk from climate change. Science, 348(6234), 571-573. https://doi.org/10.1126/scien ce.aaa4984

Wagner, D. L. (2020). Insect declines in the Anthropocene. Annual Review of Entomology, 65(1), 457-480. https://doi.org/10.1146/annurevento-011019-025151

Warren, M. S., Hill, J. K., Thomas, J. A., Asher, J., Fox, R., Huntley, B., Roy, D. B., Telfer, M. G., Jeffcoate, S., Harding, P., Jeffcoate, G., Willis, S. G., Greatorex-Davies, J. N., Moss, D., \& Thomas, C. D. (2001). Rapid responses of British butterflies to opposing forces of climate and habitat change. Nature, 414(6859), 65-69. https://doi. org/10.1038/35102054

Warren, R., Price, J., Graham, E., Forstenhaeusler, N., \& VanDerWal, J. (2018). The projected effect on insects, vertebrates, and plants of limiting global warming to $1.5^{\circ} \mathrm{C}$ rather than $2^{\circ} \mathrm{C}$. Science, 360(6390), 791-795. https://doi.org/10.1126/science.aar3646

Wiens, J. A. (1989). Spatial scaling in ecology. Functional Ecology, 3(4), 385-397. https://doi.org/10.2307/2389612

Williams, J. J., \& Newbold, T. (2020). Local climatic changes affect biodiversity responses to land use: A review. Diversity and Distributions, 26(1), 76-92. https://doi.org/10.1111/ddi.12999

\section{SUPPORTING INFORMATION}

Additional supporting information may be found in the online version of the article at the publisher's website.

How to cite this article: Redlich, S., Zhang, J., Benjamin, C., Dhillon, M. S., Englmeier, J., Ewald, J., Fricke, U., Ganuza, C., Haensel, M., Hovestadt, T., Kollmann, J., Koellner, T., Kübert-Flock, C., Kunstmann, H., Menzel, A., Moning, C., Peters, W., Riebl, R., Rummler, T., ... Steffan-Dewenter, I. (2021). Disentangling effects of climate and land use on biodiversity and ecosystem services-A multi-scale experimental design. Methods in Ecology and Evolution, 00, 1-14. https://doi.org/10.1111/2041-210X.13759 